\title{
Knowledge integration and entrepreneurial capabilities for sustainable competitive advantage through supply chain management
}

\author{
Yul Maulini ${ }^{a *}$, Erna Maulina ${ }^{b}$, Margo Purnomo ${ }^{b}$ and Muhamad Rizal ${ }^{b}$
}

${ }^{a}$ Student of Business Administration, Doctoral Program, Universitas Padjadjaran, Bandung, Indonesia

${ }^{b}$ Lecturer of Social \& Political Science Faculty, Universitas Padjadjaran, Bandung, Indonesia

\section{A B S T R A C T}

Article history:
Received December 12, 2021
Received in revised format
December 30, 2021
Accepted January 202022
Available online
January 212022
Keywords:
Knowledge Integration Capability
Entrepreneurial Capability
Supply Chain Management
Sustainable Competitive
Advantage

\section{Article history:}

Received Decemb

Available online

January 212022

Keywords:

Knowledge Integration Capability

Supply Chain Management

Advantage

\begin{abstract}
Sustainable Competitive Advantage (SCA) is very much needed in the development of the business world. This study aims to determine the model of increasing the SCA variable with Entrepreneurial Capability (EC) and Knowledge Integration Capability (KIC) directly or through Supply Chain Management (SCM) variables indirectly so that the objectives of SCA in small and medium enterprises (SMEs) can be achieved effectively. The research method used is a quantitative method with a structural model type using the SmartPLS version 3.2 program. The population in this study were all 2,296 administrators and members of IPEMI West Java. The sampling method used is random sampling. Data collection techniques using questionnaires were addressed to 360 respondents and 344 respondents were properly collected. The results show that EC influenced SCA with a T statistics score of 3.971, EC for SCM was 4.858, KIC for EC was 13.874, KIC for SCA was 1.886, KIC against SCM was 7.876, and SCM against SCA was 7.796 and it can be concluded that KIC to SCA can be significant if it is through SCM.
\end{abstract}

(C) 2022 Growing Science Ltd. All rights reserved.

\section{Introduction}

Micro, Small, and Medium Enterprises, better known as MSMEs, have a major contribution to the Indonesian economy. Based on data from the Ministry of Cooperatives and SMEs of the Republic of Indonesia from the results of the 2016 Economic Census by the Central Statistics Agency (2019), that $89.2 \%$ of the total workforce is absorbed by MSMEs, $99 \%$ of the total employment is provided by MSME actors, $60.34 \%$ of the total Gross Domestic Product was contributed by MSME actors, $58.18 \%$ of total investment was contributed by MSMEs and $14.17 \%$ of total exports were contributed by MSME actors. From this data, the role of MSMEs is very large and potential. According to the survey results from the Management and Business Laboratory of the Faculty of Economics and Business, Padjadjaran University, Bandung, data was obtained that from 350 respondents of MSME actors in the province of West Java, the following data were obtained: $47 \%$ of MSME actors stopped operating, $85 \%$ of MSMEs experienced a decrease in income of more than 30\%, 59\% MSMEs have laid off more than $30 \%$ of their employees to reduce operational costs, and $81 \%$ of MSMEs experience cash flow problems after 1 to 4 months of operation. This decline occurred during the Covid-19 pandemic, where many MSME actors not only in West Java, but nationally experienced a decline. The Indonesian Muslim Entrepreneurs Association (IPEMI) is a community organization formed and established to increase the role and contribution of Muslim women entrepreneurs in empowering the community's economy, towards economic independence with an Indonesian personality. The emergence of a knowledge-based economy is considered an important asset for generating wealth and prosperity as well as an important force for business performance. Knowledge is a source of competitive advantage for an organization that plays a major role in overcoming challenges as well as meeting opportunities. Finally, knowledge management is becoming an interesting topic in all types of organizations because of the increasing awareness of the importance of knowledge as an antecedent of business performance and organizational survival (Wang \& Lin, 2013). That is why knowledge management must be included in 
business activities in order to obtain superior performance in a sustainable manner (Gholami et al., 2013; Hussain, Xiaoyu, Si, \& Ahmed, 2011; Liu \& Abdalla, 2013; Durst \& Edvardsson, 2012).

From the perspective of knowledge integration capability, the organization is considered as an entity that integrates and distributes knowledge to produce products and services. Knowledge is recognized as the basis of the sustainable competitive advantage that many organizations have. Entrepreneurial activity has also been seen as an important feature for organizations to survive and thrive in today's turbulent environment. In this study, the authors explore the effect of entrepreneurship on organizational performance through the ability to integrate knowledge. The knowledge-based view considers the company as an entity that integrates and distributes knowledge to produce products and services (Grant 1996b). Clarify the importance of organizational capabilities, where company capabilities in addition to helping managers make the right decisions, also facilitate the formation, integration, linkage and reconfiguration of organizational resources, both internal and external (Majid et al., 2012) according to Marengo et al. (2000) enable companies to effectively solve their key problems. According to the researcher, this opinion is a consequence of the ability to manage all company resources in an integrated manner. There is one important thing that adds to the weight of organizational capabilities is that it is stable, does not change quickly, so that it is able to make the organization achieve a different competitive position from other organizations (Suryanto \& Mukhsin, 2020; Schienstock, 2009). Businesspeople in conducting business activities are based on 2 (two) main factors, namely, first, having no other activities, secondly, making commercial activities a side activity, companion to the main activity, so that it does not focus on the main activity. With the Covid-19 pandemic, businesspeople must be more critical and observant in maintaining and making their business, so that it always grows and is sustainable. This requires business insight and ability in entrepreneurship. Many MSME actors are currently turning to online businesses, but it is difficult to measure the effectiveness of MSME businesses that are not evenly distributed in selling. Empirically, it is known that entrepreneurial firms are more responsive in responding to rapid environmental changes (Utami et al., 2021; Lumpkin \& Dess, 1996; Zahra, Ucbasaran, \& Newey, 2009; HU et al., 2009). Entrepreneurial companies are also able to identify opportunities and create Competitive Advantage to exploit these opportunities (Mukhsin et al., 2022; Suryanto \& Komalasari, 2019; Hitt et al., 2012).

One form of entrepreneurial company is Small Medium Enterprise (Rumelt, 2012). MSMEs are entrepreneurial companies and are the main objects in the study of Competitive Advantage (Barney, 1991; Peteraf, 1993). The theoretical rationale for this research is referring to the Knowledge Based View which is a derivative of strategic management (David \& Carolina, 2011; Rumelt et al., 1991; Teece, 1998a; Teece et al., 1998b; Wernerfelt, 1984). Several studies show other factors needed to achieve business performance. A study conducted by Wang and Lin (2013) shows that there is a company failure to achieve superior performance even though the owner has well-educated or knowledgeable human resources. From their research, it is revealed that poor performance and business failure are mainly due to lack of innovation. The main component of innovation is the ability to conduct research and development of new products and strengthen competitiveness to improve business performance in a sustainable manner (Foret et al., 2014; Krishnaswamy, 2014; Khurum et al., 2015). Innovation is the result of the interaction of various complementary and complementary resources (Landry et al., 2002). Trott (2009) states that the complexity of innovation emphasizes three important steps in the innovation process including: generating new knowledge for innovation, using the acquired knowledge to produce new products and processes, and gaining economic benefits from new products launched in the market. Knowledge integration capabilities can also be an antecedent to the level of innovation in an organization. Suli et al. (2011) found that there is a significant relationship between knowledge based dynamic capabilities and innovation performance. In a dynamic market situation, companies must be skilled in utilizing both internal and external resources to cope with the ever-changing environment. Knowledge integration capability emphasizes the company's constant search for acquiring, generating and combining/reconfiguring the knowledge resource base. Gold et al. (2001), identified elements of knowledge management capability consisting of two dimensions, namely knowledge infrastructure capability and knowledge process capability. Knowledge infrastructure capability includes technology, structure, and culture; while process knowledge management includes the organization's ability to acquire knowledge, convert, apply, and protect it. An effective knowledge infrastructure is very much needed in the knowledge management process which has the aim of storing, transforming, and transferring knowledge (Fan et al., 2009). The most valuable resource is knowledge ( Grant, 1996a; Grant, 1996b; Kogut \& Zander, 1992; Spender, 1996).

The concept of Knowledge Base View (KBV) is to consider companies as institutions that apply knowledge by integrating explicit and implicit knowledge. It is also considered as a goal-oriented competence and activity, rather than as an abstract 'about knowledge' (Spender, 1996). Spender's research suggests that the main determinants of good performance stem from heterogeneous and ability-based knowledge (Deeds \& Decarolis, 1999), knowledge application(Grant, 1996b), and the dissemination and use of knowledge (Teece, 1998b). KBV provides important insights into why companies exist and will continue to exist and thus why organizing knowledge is an important part of what companies do. Building and enhancing core competencies are capabilities, which are fundamental to a firm's competitive advantage(Prahalad \& Hamel, 1990). Based on its combinative capabilities, the ability of a company depends on its ability to generate new combinations of existing knowledge and to exploit its knowledge of untapped potential value (Kogut \& Zander, 1992). Knowledge integration capabilities are important for gathering and accumulating individual knowledge, which then results in effective knowledge management (KM) at the organizational level (Alavi \& Tiwana, 2002; Alavi et al., 2005). The knowledge integration capability mechanism is very important to build core competencies for competitive advantage. According to KBV, the company is superior in facing market challenges because of its ability to integrate knowledge between individuals (Sabherwal \& Becerra-Fernandez, 2003). Sustainable competitive advantage (SCA) is influenced by the ability to integrate knowledge 
(KIC) mediated by entrepreneurial capability (EC) through business process results (BOP), in Muslim women's businesses in West Java.

Based on empirical studies of previous research, there is no construct that tries to explain the concept of research thinking. The variables studied are Knowledge Integration Capability, Entrepreneurial Capability, Supply Chain Management, and Sustainable Competitive Advantage not yet in one research framework. So Novelty in this research is that there is no research on Knowledge Integration Capability related to Supply Chain Management in MSMEs. There is no research on Sustainable Competitive Advantage related to Knowledge Integration Capability in MSMEs. There is no research on Entrepreneurial Capabilities in MSMEs with certain gender characteristics.

\section{Theoretical review}

\subsection{Bibliometric}

Mapping the data using VOS viewer produces a visualization of the author citation network. This allows us to further examine how the most prolific authors on intellectual capital cite each other's work. The bubble size indicates the number of publications. The bubbles indicate the average year of publication. Two bubbles are close if the two authors' themes quote each other more often (van Eck \& Waltman, 2010). The color indicates that there are two research clusters. The first group in red represents research with interrelated themes, namely the ability to integrate knowledge, integration, knowledge, relationships, research, companies, and empirical studies. The green color shows the second group with the themes of study, innovation, and firm.

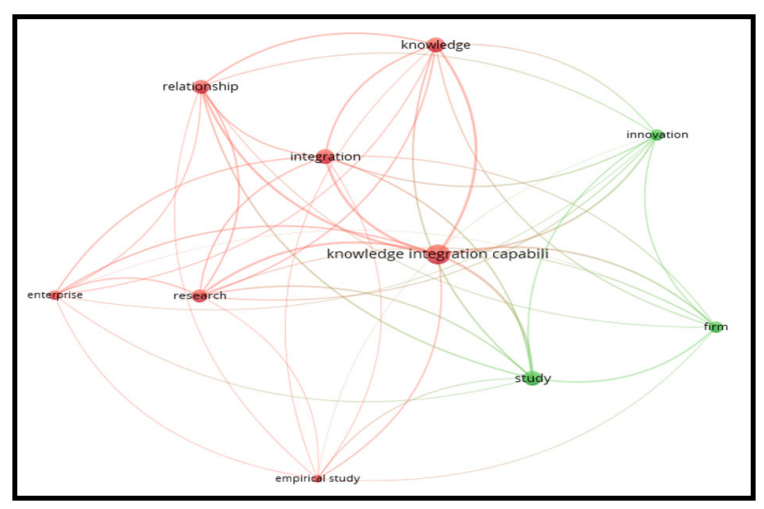

Fig. 1. Knowledge Integration Capability Bubble Map using VOS viewer v.1.6.15

\subsection{Knowledge Integration Capability}

Much research has been collected so far on the problem of why companies often fail in the process of commercializing technology and how they can overcome these difficulties (Quinn \& Mueller, 1963). Quinn and Muller have emphasized the failure of coordination between research and development organizations. Because of their different short-term goals, sense of time and cost in project work, and degree of predictability, communication between research and development centers are often discouraged (Wood \& Brown, 1998). Informal means of communication and bonding are believed to help set clear common goals and synchronize tasks between groups (Cohen et al., 1979). Knowledge integration capability is the organizational capacity to combine and synthesize technology and market-related knowledge that would otherwise be dispersed within the organization(Salunke et al., 2019). Knowledge Integration Capability (KIC) is the company's ability to synthesize and apply existing and acquired knowledge in pursuing business opportunities. In the current research, KIC is defined as the capacity of a project-oriented firm to intentionally create new knowledge from a combination of knowledge resources, extend that knowledge into value-creating activities and modify that knowledge to cope with changing market conditions (Kogut \& Zander, 1992).

\subsection{EntrepreneurialCapability}

Currently, research has studied the relationship between resource-based theory and entrepreneurship, thereby answering some important questions in entrepreneurship from a resource-based perspective. Entrepreneurs develop and use entrepreneurial abilities and resources to use the rich environment for entrepreneurial interests (Lin et al., 2006). Entrepreneurial ability refers to the ability to carry out the functions required in the early stages of business formation. Mosakowski reported a positive relationship between entrepreneurial resources and organizational competitiveness in the context of organizational choice for established firms (Mosakowski, 1998). Lipparini and Sobrero convey that entrepreneurs play a role in promoting and managing an innovative set of external relationships. Entrepreneurs who start large companies 
need to have the necessary capabilities for assembling substantial resources (Lipparini \& Sobrero, 1994). El-Namaki relates the failure of small businesses to management competencies and general competencies of entrepreneurs in the entrepreneurial process, namely centralization of power, lack of strategic planning, lack of technological innovation, and others (El-Namaki, 1990). Ibrahim and Goodwin found that entrepreneurial behavior and managerial skills are two key factors in managing small businesses (Ibrahim \& Goodwin, 1986).

\subsection{Supply Chain Management}

Supply Chain Management (SCM) has emerged in the late 1980s (Harland, 1996) and can be described as the systematic and strategic coordination of traditional business and functions across business functions within an organization and across businesses within the supply chain for the purpose of improving long-term performance. of each organization and the supply chain. SCM has been defined to explicitly recognize the strategic nature of coordination between trading partners and to explain the dual purpose of SCM: to improve organizational performance and to improve supply chain performance. SCM can also be defined as a chain that connects every element of the manufacturing and supply process from raw materials to finished products, spanning multiple organizational boundaries (Scott \& Westbrook, 1991; New \& Payne 1995). According to a broad definition, SCM covers the entire value chain and addresses the management of materials and supplies from the extraction of raw materials to the end of their useful lives (Tan, 2001).

\subsection{Sustainable Competitive Advantage}

Barney (1991) defines Sustainable Competitive Advantage as a company that implements a value creation strategy that is not in tandem with existing or developing competitors, and also argues that a company is said to have a sustainable competitive advantage when it realizes the value creating strategy, not simultaneously. by competitors or when other firms are unable to reproduce the benefits of the strategy. Barney, (1991) also shows that competitive advantage is sustainable or not, depending on the possibility of competitive duplication. According to Lippman and Rumelt (1982), competitive advantage is maintained only if it exists after attempts to duplicate it have ended (Barney 1991). In theory, the definition of a sustainable competitive advantage has: many advantages, not the least of which avoids the problem of determining the calendar length of time firms in different industries must enjoy a competitive advantage for these advantages to be "sustainable". To achieve the company's performance within the scope of sustainable competitive advantage, the decision about the company's competitive strategy that is influential is one of the main problems for the director under the business level strategy. Because the formulation and achievement of a competitive business strategy that will expand performance is one of the competent methods to realize a company's sustainable competitive advantage.

\subsection{Theoretical Thinking Framework}

The theoretical framework of research can be described as follows:

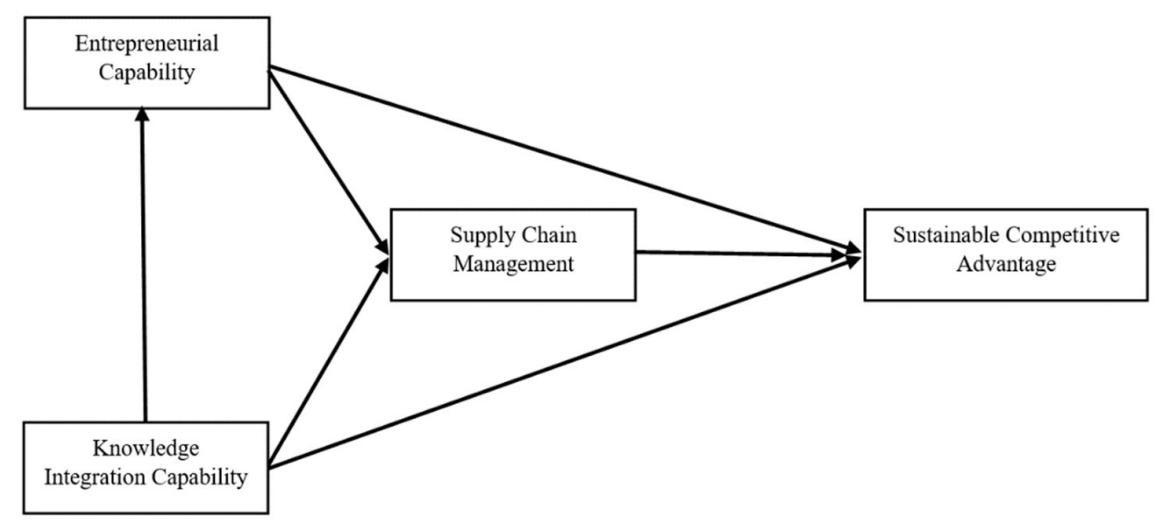

Fig. 2. Theoretical Thinking Framework

The variables studied do not occur simultaneously, so the model under study can be seen according to the time phase of the incident. The description of the time phase of the event can be described as follows:

\begin{tabular}{|c|c|c|c|c|c|c|}
\hline $\begin{array}{c}\text { Knowledge Integration } \\
\text { Capability } \\
\end{array}$ & $\rightarrow$ & Entrepreneurial Capability & $\rightarrow$ & Supply Chain Management & $\rightarrow$ & $\begin{array}{c}\text { Sustainable Competitive } \\
\text { Advantage }\end{array}$ \\
\hline INPUT & & PROCESS & & OUTCOME & & BENEFIT/IMPACT \\
\hline
\end{tabular}

Fig. 3. Conceptual Model based on Time Phase 


\subsection{Research Hypothesis}

\subsubsection{The Effect of Knowledge Integration Capability on Entrepreneurial Capability}

Companies can create new knowledge and use it as a source of continuous innovation to outperform competitors through effective entrepreneurship (Dess et al., 2003; Kazanjian et al., 2008). The entrepreneurial activity can improve organizational performance by creating new knowledge because knowledge is an important source for entrepreneurial companies that want to build competitive advantage (Ireland et al., 2003). Then

\section{$\mathbf{H}_{1}$ : Knowledge Integration Capability has a positive impact on Entrepreneurial Capability.}

\subsubsection{Effect of Knowledge Integration Capability on Supply Chain Management}

Knowledge Integration Capability performing separate production tasks is at the core of organizational capability. It is defined as the ability of firms to repeatedly perform production tasks related either directly or indirectly to their capacity to create value through the effect of turning inputs into outputs (Grant, 1996a). Because knowledge is an important input in all production processes and efficiency is created and stored by individuals in a special form. Some researchers argue that, integrating and applying knowledge. between members through the Supply Chain will lead to considerable benefits for the organization, because for example, reducing costs and cycle times, improving the quality and level of customer service (Ofek and Sarvary, 2001; Dalpati et al., 2010). Knowledge management of the supply chain will improve the quality of the effectiveness and efficiency of supply chain processes (Schoenherr et al., 2014) as well as long-term viability, competitive advantage and higher performance (Sambasivan et al., 2009; Abdul Wahab \& Sardabi, 2011). This study proposes

\section{$\mathbf{H}_{2}$ : Knowledge Integration Capability has a positive impact on Supply Chain Management.}

\subsubsection{Effect of Entrepreneurial Capability on Supply Chain Management}

Studies involving constructs such as effective knowledge management, firm market orientation, innovation and organizational outcomes are relatively abundant in the literature; However, despite the limitations of this study, we did not find any studies linking all these constructs together. The concept of dynamic capabilities is rarely applied to supply chain relationships between small and large companies (Woldesenbet, \& Jones, 2011). According to several authors (Arthur, 1999; Drucker, 1993, Hooley et al., 2001), knowledge can enhance a company's ability to perceive the market, its changes, and intricacies, and thereby direct the company to stay ahead of these changes, serving its customers in a way that more effective and efficient, in addition to providing new business opportunities. Woldesenbet and Jones (2011) argue that such a decision to enter and operate in a new product market requires small firms to adopt a heuristic-based approach to decision-making rather than a rational-based one, large. Organization. Therefore, small firms use their intuition and heuristics to enter the ambiguous and uncertain mainstream market, through their supply chain relationships with LPOs (Alvarez \& Busenitz, 2001).

\section{$\mathrm{H}_{3}$ : Entrepreneurial Capability has a positive impact on Supply Chain Management.}

\subsubsection{Effect of Entrepreneurial Capability on Sustainable Competitive Advantage}

The future of the company depends on the interpretation of the current uncertain business environment. To ensure future success, the strategic direction of the organization must be determined by anticipating future environmental needs. To succeed in this environment, general managers need to have the mindset and skills to interpret the direction the environment is taking. Entrepreneurship refers to a set of service mechanisms targeted at generating entrepreneurs and is commonly called a business incubator. This category involves an analytical approach that differs from the previous category in that business incubators are defined as "self-employed". Incubators can be regarded as machines or laboratories to "generate" entrepreneurship rather than innovation (Djellal \& Gallouj, 2013).

\section{H4: Entrepreneurial Capability has a positive impact on Sustainable Competitive Advantage.}

\subsubsection{The Effect of Knowledge Integration Capability on Sustainable Competitive Advantage}

The development of customer-focused solutions involves building operational relationships and extensive information exchange (Day, 2000; Morgan \& Hunt, 1999), leading to long-term collaborative relationships with clients. Sustainable competitive advantage refers to a company's ability to achieve a superior market position. We adopt the definition of SCA "A firm is said to have SCA when it implements a value creation strategy that is not simultaneously implemented by current or potential competitors and when these other firms cannot duplicate the advantages of this strategy. The combination of knowledge resources is particularly relevant to a service firm that project-oriented because they are task-oriented, adaptable, and flexible, and are aimed at providing specialized services to clients (Acha et al., 2005). These companies produce complex solutions for their clients which usually involve the integration of multiple knowledge sources (Acha et al., 2005). Blindenbach-Driessen \& van den Ende, 2006). Therefore, the sustainability of competitive advantage for project-based firms is deeply rooted in the complexities involved in the knowledge integration process (Gann \& Salter, 1998; Whitley, 2006). 
H5: Knowledge Integration Capability has positive impact on sustainability able Competitive Advantage.

\subsubsection{Effect of Supply Chain Management on Sustainable Competitive Advantage}

Lack of advancement and technological sophistication can limit the use of resources. Avoidance of the technological aspect by traditional managers holds the highest priority. Traditional managers are reluctant to accept new changes in technology or adopt any elements of technology. Lack of innovation due to bad equipment is not a priority for refurbishment. Because poor equipment knowledge couldn't spread smoothly. The absence of data and information security in the supply chain ranks next. The lack of sophistication leads to the management of data and information systems in a holistic supply chain. For technology transformation or new product development, technical support is very important from the manufacturer so that the task can be completed on time with the vendor. Then

H6: Supply Chain Management has a positive impact on Sustainable Competitive Advantage.

\section{Research Methods}

\subsection{Design}

This research was conducted on Muslim Small and Medium Enterprises in West Java. According to Sugiyono (2017), the object of research is an attribute or nature or value of people, objects or activities that have certain variations set by researchers to be studied and then drawn conclusions. The object of research is the variable or what is the point of attention of a study, while the research subject is the place where the variable is attached. The research objects studied were Knowledge Integration Capabilities (X1), Entrepreneurial Capability (X2), Supply Chain Management (X3), and Sustainable Competitive Advantage (Y1). This study uses inferential analysis using multiple variants. This is done to record, process, present and interpret data to provide a real picture of Micro, Small and Medium Enterprises Muslimah in West Java. This research was conducted through a quantitative approach, to test the hypothesis by proving the relationship between each variable. In this study, there are two sources of data, namely primary and secondary data.

\subsection{Population and sample}

Neuman (1994) states that what is meant by population is the universe or the whole object of research in the form of people, groups, organizations, written documents or symbolic messages, even social actions that can be measured and have an important role in sampling. Zikmund (2003) further explains that the research population must have a clear target population so that the determination and sampling are not mistargeted. Based on the population target above, the researcher then refers to the IPEMI 2020 data in West Java. The data shows that there are 2,296 Muslim businesses from 16 cities or regencies in West Java, Indonesia. Sampling in this study was carried out using a probability sampling technique. Probability sampling technique is a sampling method that provides an equal opportunity to be taken for each element of the population. This technique is a sampling strategy that is commonly used in quantitative research and aims to achieve representativeness (Teddlie \& Yu, 2007). This sampling was chosen with the consideration that every small and medium-sized Muslim business in West Java has the same opportunity to represent the business they do. Second, every Muslim business engaged in the business sector has a certain amount to be sampled. The calculation above can be explained as follows. Based on data from IPEMI there are $\mathrm{N}=2296$. Based on the $95 \%$ confidence level, it is known that $d=0.005$. The results show that the sample $n=344.152$ or rounded to 344 .

\section{Measurement Model}

The discussion of the research results is carried out with the output path coefficients using SmartPLS. The discussion of the research construct on variable X data is data related to Knowledge Integration Capability (X1), Entrepreneurial Capability (X2), Supply Chain Management (X3), while data on variable Y is Sustainable Competitive Advantage (Y).

\subsection{Characteristics of Respondents}

The general characteristics of the respondents are an explanation of the IPEMI data (Indonesian Muslim Entrepreneurs Association) in the service sector as a unit of analysis to provide a comprehensive description of the research results. This description is the initial information from the survey results to assess the characteristics of respondents who are able to represent the population, or in other words whether information from respondents with various characteristics can explain the problems of a number of research constructs. The answers from respondents to the questionnaire were 368 . Data duplication was found in as many as 24 respondents, so the total data analyzed were 344 . This means that the response rate is $93.47 \%$ of the sample calculation. Based on the opinion(Hair et al., 2014)the number of respondents of 200 respondents has been able to meet the minimum data calculation for SEM-PLS.

\subsection{Outer Model Results}

Fig. 4 and Table 1 present the results of the outer model. 


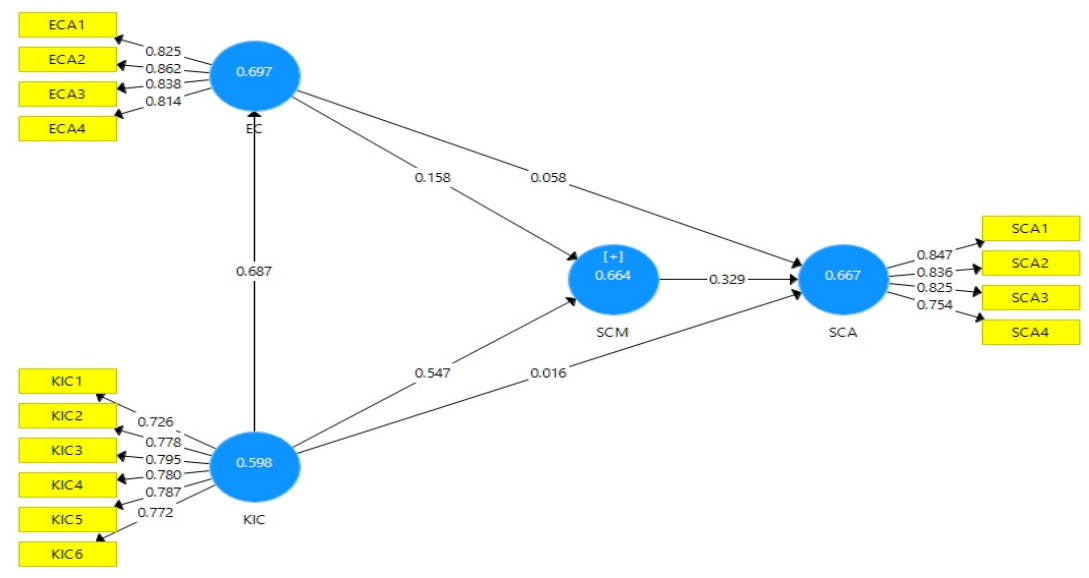

Fig. 4. Figure Research Model

Table 1

Path Coefficients (Mean, STDEV, T-Values, P-Values)

\begin{tabular}{lcccc}
\hline & $\begin{array}{c}\text { Original } \\
\text { Sample }(\mathrm{O})\end{array}$ & $\begin{array}{c}\text { Sample } \\
\text { Mean }(\mathrm{M})\end{array}$ & Standard Deviation (STDEV) & T Statistics $(|\mathrm{O} / \mathrm{STDEV}|)$ \\
\hline $\mathrm{EC} \rightarrow \mathrm{SCA}$ & 0.197 & 0.198 & 0.050 & 3.971 \\
$\mathrm{EC} \rightarrow \mathrm{SCM}$ & 0.307 & 0.306 & 0.063 & 4.858 \\
$\mathrm{KIC} \rightarrow \mathrm{EC}$ & 0.638 & 0.640 & 0.046 & 0.000 \\
$\mathrm{KIC} \rightarrow \mathrm{SCA}$ & 0.119 & 0.121 & 0.063 & 0.000 \\
$\mathrm{KIC} \rightarrow \mathrm{SCM}$ & 0.572 & 0.570 & 0.073 & 0.000 \\
$\mathrm{SCM} \rightarrow \mathrm{SCA}$ & 0.566 & 0.566 & 0.073 & 0.059 \\
\hline
\end{tabular}

\subsection{Discussion of Research Data Analysis Results}

\subsubsection{The Effect of Knowledge Integration Capability on Entrepreneurial Capability}

The first hypothesis is shown, in the analysis of the Outer Model and the analysis of the Inner Model there are significant results, seen between the relationship between the two variables. Knowledge Integration Capability variable that affects Entrepreneurial Capability. In the Indirect Effect analysis, it was found that the two variables had a direct influence on each other. Calculation of latent variables that are influenced by other latent variables Entrepreneurial Capability using R-Square variable has a value of 0.41 which means moderate. The Variance Inflation Factor or collinearity test of the two variables has a value that is free from collinearity symptoms. The effect of the predictor variable on the dependent variable between Knowledge Integration Capability and Entrepreneurial Capability is $\mathrm{f}$-square 0.69 and thus has a strong influence. In the Indirect Effect analysis, it was found that the results of the two variables had a direct influence on each other. In accordance with previous research. Entrepreneurial activity can improve organizational performance by creating new knowledge because knowledge is an important source for entrepreneurial companies that want to build competitive advantage (Ireland et al., 2003). Companies can create new knowledge and use it as a source of continuous innovation to outperform competitors through effective entrepreneurship (Dess et al., 2003; Kazanjian et al., 2008).

\subsubsection{Effect of Knowledge Integration Capability on Supply Chain Management}

The second hypothesis is shown, in the Outer Model analysis and Inner Model analysis there are significant results that are seen in the relationship between the two variables. Knowledge Integration Capability variable affects Supply Chain Management. In the construct validity test using Discriminant Validity, the construct of values has an adequate discriminant which means that discriminant validity is achieved after being tested. Calculation of latent variables that are influenced by other latent variables Supply Chain Management using the R-Square variable has a value of 0.65 which means moderate. The Variance Inflation Factor or collinearity test of the two variables has a value that is free from collinearity symptoms. The effect of the predictor variable on the dependent variable between the Knowledge Integration Capability variable and Supply Chain Management is f-Square 0.55 and thus has a strong influence. In the Indirect Effect analysis, it was found that the results of the two variables had a direct influence on each other.

\subsubsection{Effect of Entrepreneurial Capability on Supply Chain Management}

The third hypothesis is shown, in the analysis of the Outer Model and the analysis of the Inner Model there are significant results seen between the relationship between the two variables. Entrepreneurial Capability variable affects Supply Chain 
Management. In the construct validity test using Discriminant Validity, the construct of values has an adequate discriminant which means that discriminant validity is achieved after being tested. Calculation of latent variables that are influenced by other latent variables Entrepreneurial Capability using r-Square variable has a value of 0.41 which means moderate, Supply Chain Management using r-Square variable has a value of 0.65 which means moderate. The Variance Inflation Factor or collinearity test of the two variables has a value that is free from collinearity symptoms. The effect of the predictor variable on the dependent variable between Entrepreneurial Capability and Supply Chain Management is f-Square 0.16 and thus has a moderate effect. In the Indirect Effect analysis, it was found that the results of the two variables had a direct influence on each other. Thus according to previous research, experienced businessmen identify more business opportunities than novice entrepreneurs(Ucbasaran et al., 2008). Entrepreneurial Capability has a positive and significant effect on the global market performance of a company (Day, 2001, Slater \& Narver, 1995). Firm orientation to the market is also constantly associated with learning(Zhang et al., 2008).

\subsubsection{Effect of Entrepreneurial Capability on Sustainable Competitive Advantage}

The fourth hypothesis is shown, in the analysis of the Outer Model and the analysis of the Inner Model there are significant results seen between the relationship between the two variables. Entrepreneurial Capability variable affects Sustainable Competitive Advantage. In the construct validity test using Discriminant Validity, the construct of values has an adequate discriminant which means that discriminant validity is achieved after being tested. Calculation of latent variables that are influenced by other latent variables Entrepreneurial Capability using r-Square variable has a value of 0.41 which means moderate, Sustainable Competitive Advantage using r-Square variable has a value of 0.66 which means moderate. The Variance Inflation Factor or collinearity test of the two variables has a value that is free from collinearity symptoms. The effect of the predictor variable on the dependent variable between Entrepreneurial Capability and Sustainable Competitive Advantage is f-Square 0.06 and thus has a weak effect. In the Indirect Effect analysis, it was found that the results of the two variables had a direct influence on each other.

Thus, according to previous research, To succeed in this environment, general managers need to have the mindset and skills to interpret the direction taken by the environment. Entrepreneurship Capability (EC) and market culture in organizations contribute to organizational competitive advantage by increasing organizational performance (Antoniou \& Ansoff, 2004). EC can be defined as a distinct set of individual and organizational abilities and skills as well as action practices, and routines aimed at exploring, integrating and exploiting untapped business opportunities in the context of an institutionalized marketplace (Villani \& Antonietti, 2020).

\subsubsection{Effect of Knowledge integration Capability on Sustainable Competitive Advantage}

The fifth hypothesis is shown, in the Outer Model analysis and Inner Model analysis there are significant results seen between the relationship between the two variables. The Knowledge integration Capability variable affects the Sustainable Competitive Advantage. In the construct validity test using Discriminant Validity, the construct of values has an adequate discriminant which means that discriminant validity is achieved after being tested. Calculation of latent variables that are influenced by other latent variables Sustainable Competitive Advantage using the r-Square variable has a value of 0.66 which means moderate or sufficient. The Variance Inflation Factor or collinearity test of the two variables has a value that is free from collinearity symptoms. The effect of the predictor variable on the dependent variable between Entrepreneurial Capability and Sustainable Competitive Advantage is $\mathrm{f}_{\text {-square }} 0.02$ thus has a weak influence.

\subsubsection{Effect of Supply Chain Management on Sustainable Competitive Advantage}

The fifth hypothesis is shown, in the Outer Model analysis and Inner Model analysis there are significant results seen between the relationship between the two variables. Supply Chain Management variables affect the Sustainable Competitive Advantage. In the construct validity test using Discriminant Validity, the construct of values has an adequate discriminant which means that discriminant validity is achieved after being tested. Calculation of latent variables that are influenced by other latent variables Supply Chain Management using the R-Square variable has a value of 0.65 which means moderate, Sustainable Competitive Advantage using the r-Square variable has a value of 0.66 which means moderate or sufficient. The Variance Inflation Factor or collinearity test of the two variables has a value that is free from collinearity symptoms. The effect of the predictor variable on the dependent variable between Entrepreneurial Capability and Sustainable Competitive Advantage is f-Square 0.33 and thus has a moderate effect. In the Indirect Effect analysis, it was found that the results of the two variables had a direct influence on each other. Lack of advancement and technological sophistication can limit the use of resources. Avoidance of the technological aspect by traditional managers holds the highest priority. Traditional managers are reluctant to accept new changes in technology or adopt any elements of technology.

\subsection{Confirm Theory}

Based on the research objectives, theoretical benefits, test results, and discussion, it is known that the overall research model supports the Grand Theory used in this study, namely the Knowledge Base View proposed by Theory Dynamics. 
Table 2

Confirmation of Theory

\begin{tabular}{|c|c|c|c|c|}
\hline No. & $\begin{array}{c}\text { Track } \\
\text { Construct }\end{array}$ & $\begin{array}{l}\text { Basic Theory of Relationships } \\
\text { Between Constructs }\end{array}$ & Previous Research & Confirmation \\
\hline 1. & KBV - KIC & Knowledge-Based View (KBV) & $\begin{array}{l}\text { Davenport and Klahr 1998; Grant and } \\
\text { Baden-Fuller 1995; Grant 1996b }\end{array}$ & Received \\
\hline 2. & $\mathbf{K I C}-\mathbf{E C}$ & Knowledge-Based View (KBV) & $\begin{array}{l}\text { Erikson.2002; Barney, 1991; Ulrich's, } \\
\text { 1998; Day, 1994; Lisboa et all, 2011; } \\
\text { Uchbasaran et al, } 2008\end{array}$ & Received \\
\hline 3. & KIC - SCM & Knowledge-Based View (KBV) & $\begin{array}{l}\text { (Wong and Wong, 2011); s (Halley and } \\
\text { Beaulieu, 2005; Chen et al., 2009; Rashed et } \\
\text { al.,2010; Abdul Wahab and Sardabi, 2011; } \\
\text { Samuel et al., 2011). }\end{array}$ & Received \\
\hline 4. & EC - SCM & Knowledge-Based View (KBV) & $\begin{array}{l}\text { (Alvarez and Busenitz, 2001); (Rauch et al., } \\
\text { 2009: 762); (Ambrosini } \\
\text { and Bowman, 2009) }\end{array}$ & Received \\
\hline 5. & EC - SCA & Knowledge-Based View (KBV) & $\begin{array}{l}\text { (Antoniou \& Ansoff, 2004); (Villani \& } \\
\text { Antonietti, 2020) }\end{array}$ & Received \\
\hline 6. & KIC - SCA & Knowledge-Based View (KBV) & (Kim et al., 2012); (Salunke et al., 2019) & Received \\
\hline 7. & SCM - SCA & knowledge-based View (KBV) & (Nakruang et al., 2020) & Received \\
\hline
\end{tabular}

Based on the results of the research discussion, the variables of Knowledge Integration Capability, Entrepreneurial Capability, Supply Chain Management, and Sustainable Competitive Advantage are not yet in a research framework. Knowledge Integration Capability (KIC) is implemented for MSMEs. A novelty for entrepreneurs at IPEMI brings up individual training for each member. Research on business success is still important to study because it can increase the economic growth of a country. The implementation of Four CS in the organization, Communication, Coordination, Cooperation, and Collaboration has a positive influence on the company's performance (Petriana, 2017). Empirical results also support a mediating role, showing that knowledge-based dynamic capabilities act like transformers that convert knowledge-sharing benefits into innovation performance (Petriana, 2017). Sustainable Competitive Advantage is associated with Knowledge Integration Capability in MSMEs. Because one of the obstacles for beginners, especially among women, is the lack of self-confidence. In this regard, encouragement and assistance will be a stepping stone to advancing.

Affiliated with a certain institution outside the MSME organization can enable the development of an increasingly competitive company, able to compete with a fast and global market. Innovating products, MSME companies metamorphose after a pandemic occurs, a metamorphosis is carried out so that companies can survive in the global crisis and decrease the intensity of product interest. Zhou and Fink (2003) mention that the presence of intellectual capital is very important for organizations to be successful in today's knowledge economy. The main determinant of business success lies in the presence or absence of strategic management related to setting long-term organizational goals and development that will maintain MSMEs in meeting the goals set (Aremu, \& Olodo, 2015). According to Guido Corbetta (2004). Entrepreneurial business teaches how to anticipate the market smartly. Entrepreneurship itself has the power to innovate, be cohesive, and balanced, which has an impact on the market economy so that it can continue to run with growth and sustainability.

\section{Conclusion}

After discussing the Knowledge Integration Capability (KIC) and Entrepreneurial Capability (EC) against Sustainable Competitive Advantage (SCA) through Supply Chain Management (SCM), conclusions and suggestions are presented. Knowledge Integrity Capability has an important role in this MSME research, which means it has a positive effect on every variable that is put forward in the discussion. In relation to the discussion of the position of manager or the equivalent, having information resources that are used as the main capital for entrepreneurship. By modifying products, evaluating and involving experts, creating innovations and the company can metamorphose to keep up with the times. MSMEs that survive in the midst of the pandemic turmoil and strong ties in the IPEMI Community create integrity in each individual to develop together, create new business opportunities and be able to export local products produced in the MSME sector. Intellectual capital is very influential in business so that any emergence or globalization can be overcome, and competitive entrepreneurship is built and continues to strengthen the nation's economy. In closing this dissertation, the author provides suggestions and input to MSMEs in Indonesia so that they can have competitive and sustainable knowledge integrity to do several things. First, exploration in technology which includes partnering to develop products and strengthen product quality and quality for export. Second, embracing experts to produce competitive products and utilizing knowledge and integrity as a reference in company management. With the development of the market, it is time to move and not be closed in their respective areas. Do not stop to innovate, be it in terms of products or thoughts and expand resources so that the business can grow.

\section{References}

Alavi, M., Kayworth, T. R., \& Leidner, D. E. (2005). An empirical examination of the influence of organizational culture on knowledge management practices. Journal of management information systems, 22(3), 191-224. https://doi.org/10.2753/MIS0742-1222220307 
Alavi, M., \& Tiwana, A. (2002). Knowledge integration in virtual teams: The potential role of KMS. Journal of the American Society for Information Science and Technology. https://doi.org/10.1002/asi.10107

Antoniou, P. H., \& Ansoff, H. I. (2004). Strategic management of technology. Technology Analysis and Strategic Management, 16(2), 275-291. https://doi.org/10.1080/09537320410001682928

Barney, J. (1991). Firm Resources and Sustained Competitive Advantage. Journal of Management. https://doi.org/10.1177/014920639101700108

Cohen, H., Keller, S., \& Streeter, D. (1979). Transfer of Technology From Research To Development. Research Management, 22(3), 11-17. https://doi.org/10.1080/00345334.1979.11756535

Deeds, D. L., \& Decarolis, D. M. (1999). The Impact of Stocks and Flows of Organizational Knowledge on Firm Performance : An Empirical Investigation of the Biotechnology Industry. Strategic Management Journal.

Dess, G. G., Ireland, R. D., Zahra, S. A., Floyd, S. W., Janney, J. J., \& Lane, P. J. (2003). Emerging issues in corporate entrepreneurship. Journal of management, 29(3), 351-378. https://doi.org/10.1016/S0149-2063(03)00015-1

Djellal, F., \& Gallouj, F. (2013). New Forms of Entrepreneurship in a Sustainable Knowledge-Based Service Economy. In Encyclopedia of Creativity, Invention, Innovation and Entrepreneurship. https://doi.org/10.1007/978-1-4614-38588429

El-Namaki, M. S. S. (1990). Small business - the myths and the reality. Long Range Planning, 23(4), 78-87. https://doi.org/10.1016/0024-6301(90)90155-W

Gold, A. H., Malhotra, A., \& Segars, A. H. (2001). Knowledge management: An organizational capabilities perspective. Journal of management information systems, 18(1), 185-214. https://doi.org/10.1080/07421222.2001.11045669

Grant, R. M. (1996a). Prospering in dynamically-competitive environments: Organizational capability as knowledge integration. Organization science, 7(4), 375-387. https://doi.org/10.1287/orsc.7.4.375

Grant, R. M. (1996b). Toward a knowledge-based theory of the firm. Strategic management journal, 17(S2), 109-122. https://doi.org/10.1002/smj.4250171110

Hair, J. F., Hult, G. T. M., Ringle, C. M., \& Marko, S. (2014). A Primer On Partial Least Squares Structural Equation Modeling (PLS-SEM) (Vicki Knight, Kalie Koscielak, \& Laura Barrett (eds.)). SAGE Publications, Inc.

Ibrahim, A. B., \& Goodwin, J. R. (1986). Perceived causes of success in small business. American journal of small business, 11(2), 41-50. https://doi.org/10.1177/104225878601100204

Ireland, R. D., Hitt, M. A., \& Sirmon, D. G. (2003). A model of strategic entrepreneurship: The construct and its dimensions. Journal of management, 29(6), 963-989. https://doi.org/10.1016/S0149-2063(03)00086-2

Kazanjian, R. K., Drazin, R., \& Glynn, M. A. (2008). Implementing Strategies for Corporate Entrepreneurship: A Knowledge-Based Perspective. In Strategic Entrepreneurship: Creating a New Mindset, 173-199. https://doi.org/10.1002/9781405164085.ch9

Kim, Y. J., Song, S., Sambamurthy, V., \& Lee, Y. L. (2012). Entrepreneurship, knowledge integration capability, and firm performance: An empirical study. Information Systems Frontiers, 14(5), 1047-1060. https://doi.org/10.1007/s10796-0119331-z

Kogut, B., \& Zander, U. (1992). Knowledge of the firm. Combinative capabilities, and the replication of technology. Organization Science, 3(3), 383-397. https://doi.org/10.2307/2635279

Lin, B. W., Li, P. C., \& Chen, J. S. (2006). Social capital, capabilities, and entrepreneurial strategies: A study of Taiwanese high-tech new ventures. Technological Forecasting and Social Change, 73(2), 168-181. https://doi.org/10.1016/j.techfore.2004.12.001

Lipparini, A., \& Sobrero, M. (1994). The glue and the pieces: Entrepreneurship and innovation in small-firm networks. Journal of Business Venturing.

Mosakowski, E. (1998). Entrepreneurial Resources, Organizational Choices, and Competitive Outcomes. Organization Science. https://doi.org/10.1287/orsc.9.6.625

Mudrajad, K. (2003). Metode Riset untuk bisnis dan ekonomi. Jakarta: Erlangga.

Mukhsin, M., Taufik, H., Ridwan, A., \& Suryanto, T. (2022). The mediation role of supply chain agility on supply chain orientation-supply chain performance link. Uncertain Supply Chain Management, 10(1), 197-204.

Nakruang, D., Donkwa, K., \& Suvittawat, A. (2020). The causal factors influencing corporate sustainability performance: Case of community smes in three Southern Border Provinces, Thailand. Entrepreneurship and Sustainability Issues, 7(3), 1459-1471.

Neuman, W. L. (1994). Social Research Methods: Qualitative and Quantitative Approaches. Allyn and Bacon.

Petriana, B. (2017). The Perceived Destination Image of Indonesia: An Assessment on Travel Blogs Written by the Industry's Top Markets. 1-140.

Prahalad, C. K., \& Hamel, G. (1990). The core competence and the corporation. Harvard Business Review.

Quinn, J. B., \& Mueller, J. A. (1963). Transferring Research Results to Operations. Harvard Business Review.

Sabherwal, R., \& Becerra-Fernandez, I. (2003). An empirical study of the effect of knowledge management processes at individual, group, and organizational levels. Decision sciences, 34(2), 225-260. https://doi.org/10.1111/1540-5915.02329

Salunke, S., Weerawardena, J., \& McColl-Kennedy, J. R. (2019). The central role of knowledge integration capability in service innovation-based competitive strategy. Industrial Marketing Management, 76, 144-156. https://doi.org/10.1016/j.indmarman.2018.07.004

Spender, J. C. (1996). Making knowledge the basis of a dynamic theory of the firm. Strategic management journal, 17(S2), 45-62. https://doi.org/10.1002/smj.4250171106 
Sugiyono. (2017). Metode Penelitian Bisnis (Pendekatan Kuantitatif, Kualitatif, Kombinasi dan R\&D). In Metodelogi Penelitian.

Suryanto, T., \& Mukhsin, M. (2020). Mediation of supply chain integration on the relationship between market orientation with company performance. Uncertain Supply Chain Management, 8(4), 739-744.

Suryanto, T., \& Komalasari, A. (2019). Effect of mandatory adoption of international financial reporting standard (IFRS) on supply chain management: A case of Indonesian dairy industry. Uncertain Supply Chain Management, 7(2), 169-178.

Tanriverdi, H. (2005). Information technology relatedness, knowledge management capability, and performance of multibusiness firms. MIS Quarterly: Management Information Systems, 29(3), 311-334. https://doi.org/10.2307/25148681

Teddlie, C., \& Yu, F. (2007). Mixed methods sampling: A typology with examples. Journal of Mixed Methods Research, l(1), 77-100.

Teece, D. J. (1998a). Capturing value from knowledge assets: The new economy, markets for know-how, and intangible assets. California management review, 40(3), 55-79. https://doi.org/10.2307/41165943

Teece, D. J. (1998b). Capturing value from knowledge assets: The new economy, markets for know-how, and intangible assets. California management review, 40(3), 55-79.

Ucbasaran, D., Westhead, P., \& Wright, M. (2008). Opportunity identification and pursuit: does an entrepreneur's human capital matter?. Small business economics, 30(2), 153-173. https://doi.org/10.1007/s11187-006-9020-3

Utami, P., Ali, J., \& Salleh, M. S. (2021). Supply Chains In Indonesia Facing Virus Corona (COVID-19): Models Innovation And Obstacles Faced. Bina Bangsa International Journal Of Business And Management, 1(1), 1-12.

Van Eck, N. J., \& Waltman, L. (2010). Software survey: VOSviewer, a computer program for bibliometric mapping. scientometrics, 84(2), 523-538. https://doi.org/10.1007/s11192-009-0146-3

Villani, D., \& Antonietti, A. (2020). Measurement of Creativity. In Encyclopedia of Creativity, Invention, Innovation and Entrepreneurship. https://doi.org/10.1007/978-3-319-15347-6_377

Wood, S. C., \& Brown, G. S. (1998). Commercializing nascent technology: The case of laser diodes at Sony. Journal of Product Innovation Management, 15(2), 167-183. https://doi.org/10.1111/1540-5885.1520167

Zhang, X. Di, Zhao, S. Z., Wang, J., \& Xu, H. (2008). The key factors affecting knowledge integration capability. 2008 International Conference on Wireless Communications, Networking and Mobile Computing, WiCOM 2008, 1-4. https://doi.org/10.1109/WiCom.2008.2558

Zikmund, W. G., McLeod, R., \& Gilbert, F. W. (2003). Customer relationship management: Integrating marketing strategy and information technology. Wiley. 
(c) (1)
(C) 2022 by the authors; licensee Growing Science, Canada. This is an open access article distributed under the terms and conditions of the Creative Commons Attribution (CC-BY) license (http://creativecommons.org/licenses/by/4.0/). 